\title{
Effect of Potassium and Nitrogen Fertilization on Some Macronutrients Utilization Efficiency by Wheat
}

\author{
I. S. Mosaad ${ }^{1}$ and K. F. Fouda ${ }^{2}$ \\ ${ }^{1}$ Soils, Water and Environment Research Institute, Agricultural \\ Research Center, Giza and ${ }^{2}$ Soil Dept., Fac. of Agric., \\ Mansoura Univ., Egypt.
}

\begin{abstract}
TO STUDY the effect of potassium and nitrogen fertilization treatments on wheat yield, P \& K uptake and P \& $\mathrm{K}$ utilization efficiency for wheat (Triticum aestivum, L.), variety Sakha 93, two field experiments were conducted on a clay saline soil at El-Serw Agricultural Research Station, Agricultural Research Center, Egypt during 2011/2012 and 2012/2013 winter seasons. The experiments were carried out in a split plot design with four replicates. Main plots were assigned to potassium applications $\left(0,47.4 \& 94.8 \mathrm{~kg} \mathrm{~K} \mathrm{ha}^{-1}\right)$. The sub plots were divided by mineral nitrogen treatments as follows: $44.5,89,133.5,178$ and $214 \mathrm{~kg} \mathrm{~N} \mathrm{ha}^{-1}$. Wheat yield (grain \& straw) and P \& K-uptake by (wheat grain \& straw) increased with increasing potassium rate up to $94.8 \mathrm{~kg} \mathrm{~K} \mathrm{ha}^{-1}$, but $\mathrm{P} \& \mathrm{~K}$ utilization efficiency by wheat crop was decreased. Also, these results showed that 214 , $178,133.5,89$ and $44.5 \mathrm{~kg} \mathrm{~N} \mathrm{ha}^{-1}$, respectively gave the highest values of the previous parameters except the $\mathrm{PU}_{\mathrm{t}} \mathrm{E}$ and $\mathrm{KU}_{\mathrm{t}} \mathrm{E}$, where the order of values was upward with the order of the previous treatments. The interaction between $94.8 \mathrm{~kg} \mathrm{~K} \mathrm{ha}^{-1}$ and $214 \mathrm{~kg} \mathrm{~N}^{-1}$ gave the highest wheat yield (grain \& straw) and $\mathrm{P} \& \mathrm{~K}$ uptake by grain and straw and gave the lowest $\mathrm{PU}_{\mathrm{t}} \mathrm{E}$ and $\mathrm{KU}_{\mathrm{t}} \mathrm{E}$ in both seasons. So, it is preferred to add $94.8 \mathrm{~kg} \mathrm{~K}$ and $214 \mathrm{~kg} \mathrm{~N} \mathrm{ha}^{-1}$ to economic production of wheat grain and straw especially in saline soil. Also, the highest results of $\mathrm{PU}_{\mathrm{t}} \mathrm{E}$ and $\mathrm{KU}_{\mathrm{t}} \mathrm{E}$ in both seasons were obtained with interaction between $0 \mathrm{~kg} \mathrm{~K} \mathrm{ha}^{-1}$ and $44.5 \mathrm{~kg} \mathrm{~N} \mathrm{ha}^{-1}$, it indicates shortages in uptake of phosphorus \& potassium with nitrogen \& potassium deficiency.
\end{abstract}

Keywords: Wheat, Nitrogen, Potassium, Fertilization, Phosphorus, Efficiency.

Wheat (Triticum aestivum,L.) is one of the most important cereal crops not only in Egypt but all over the world. Because wheat production in Egypt is not enough for domestic consumption, this requires much attention to increase production to meet the high demand and reduce the gap between production and consumption of wheat. Therefore, great efforts have been made to achieve the best transactions and methods of agriculture to get maximum productivity of different wheat varieties with optimal quality properties.

Agricultural intensification is through the use of varieties of high production crops and the development of pesticides and chemical fertilizers, irrigation, 
mechanization has led to a significant increase in cereal production in developing countries over the past three decades (Matson et al., 1998). However, there is a growing global challenge of getting food with protecting the environment especially with the production of strategy crops such as maize, rice and wheat (Cassman et al., 2002).

Salinity becomes one of the most important and serious agricultural problems. Moreover, it is an ever-present threat to crop productivity (Termaat et al., 1985). Fertilizer management can strongly affect crop productivity under conditions of drought or salinity. Thus, the addition of nutrients can either enhance or decrease plants resistance to salinity (Gibson, 1988).

It is necessary to add fertilizer and / or amendments to supply the appropriate nutrients and get the maximum yield. Many agricultural experiments also demonstrated that the efficiency of applied fertilizers is no more than $50 \%$ of the nitrogen, $10 \%$ of the phosphorus and $40 \%$ of potassium. Plants that have high efficiency of nutrient absorption and utilization greatly enhance the efficiency of the application of fertilizers and reduce the high cost of agriculture and prevent loss of nutrients and thereby reduce environmental pollution (Baligar et al., 2001).

Potassium is one of the essential nutrients for the plants, which helps directly in the production of the crop and determines its quality. Also, potassium involved in many physiological processes such as photosynthesis, enzyme activation, water relations and assimilates transport can have direct consequences on crop productivity. Therefore, potassium deficiency can lead to a reduction in both the number of leaves produced and the size of individual leaves (Pettigrew, 2008).

Baque et al. (2006) found that the significantly improved yields, yield contributing characters and N, P and K uptake of wheat were with higher level of potassium $\left(312 \mathrm{~kg} \mathrm{ha}^{-1}\right)$. El-Abady et al. (2009) reported that foliar application of potassium at the rate of $2.49 \% \mathrm{~K}$ gave the highest values of growth, yield and its components and grain quality characters followed by $1.25 \% \mathrm{~K}$ as compared with control treatment (without potassium application). Rahimi (2012) indicated that effect of potassium on grain yield was highly significant. Tababtabaei and Ranjbar (2012) showed that the highest grain and straw yields were obtained by application of $74.7 \mathrm{~kg} \mathrm{~K} \mathrm{ha}^{-1}$.

Plants respond strongly to addition of nitrogen, which is regarded main in the construction of amino acids, proteins and enters in many physiological processes in the plant. Nitrogen fertilization is an important and essential factor affecting wheat production all over the world especially in Egypt, because most of Egyptian soils contain insufficient nitrogen. Several research conducted in Egypt proved that there is a significant effect of nitrogen levels on most of the characteristics growth, yield and yield components. The optimum nitrogen fertilizer levels for wheat in Egypt vary widely in amounts, They ranged between 97.2 and $285.7 \mathrm{~kg} \mathrm{~N} \mathrm{ha}^{-1}$ according to environmental conditions such as type and properties of soil.

Egypt. J. Soil. Sci. 56, No. 3 (2016) 
Abou-Salama et al. (2000), Antoun et al. (2010) and Rahimi (2012) found that nitrogen fertilizer at the rates of $119.1,178.6$ and $238.1 \mathrm{~kg} \mathrm{~N} \mathrm{ha}^{-1}$ significantly increased yields and its components. Also, Ahmed (2002) found that the grain yield of wheat increased by increasing nitrogen fertilizer levels up to $190.5 \mathrm{~kg} \mathrm{~N}^{-1}$, while Seleem and Abd El-Dayem (2013) reported that the best significant values of grain and straw yields were obtained by adding 142.9 or $214.3 \mathrm{~kg} \mathrm{~N} \mathrm{ha}^{-1}$.

NPK uptake by grain and straw were significantly increased by nitrogen fertilizers when raised from 59.5 to $119.1,178.6$ and $238.1 \mathrm{~kg} \mathrm{~N} \mathrm{ha}^{-1}$ (Antoun et al., 2010).

Internal utilization efficiency (IE) of a nutrient (nutrition utilization efficiency) (kg yield per kg nutrient uptake), this measurement can be interpreted by Dobermann (2007) as follows:

1- The plant's ability to transform nutrients was obtained from all sources (soil and fertilizer) to the economic return (grain).

2- Depends on genotype, environment and management.

3- A very high IE suggests deficiency of that nutrient.

4- Low IE suggests poor internal nutrient conversion due to other stresses (nutrient deficiencies, heat stress, drought stress, mineral toxicities, and pests).

Usually potassium efficiency describes the ratio of the potential yield that can be achieved under a potassium deficiency (Damon and Rengel, 2007). Varieties and genotypes which have high efficiency of potassium usually exhibit a higher capacity to take up relatively more $\mathrm{K}$ in $\mathrm{K}$ deficient soil ( $\mathrm{K}$ uptake efficiency, $\mathrm{KU}_{\mathrm{p}} \mathrm{E}$ ) (Trehan \& Sharma, 2002 and Zhang et al., 2007) and/or a higher dry matter production per unit of potassium taken up (K utilization efficiency, KUtE) (El Bassam, 1998). However, a high $\mathrm{KU}_{\mathrm{p}} \mathrm{E}$ or $\mathrm{KU}_{\mathrm{t}} \mathrm{E}$ may not mean that a high yield or biomass, and biomass production or yield remains are the most important goals. Siddiqi and Glass (1981) proposed another index for nutrient-use efficiency as follows: the ratio of biomass and tissue nutrient concentration, simultaneously taking into account the biological production and KUE (biomass/tissue nutrient concentration).

Therefore, this investigation was established to determine the effect of mineral potassium and nitrogen applications on yield, P \& K-uptake by grain and straw and $\mathrm{P} \& \mathrm{~K}$ utilization efficiency for wheat under the environmental conditions of El-Serw District, Damietta Governorate.

\section{Materials and Methods}

\section{Experimental design and preparing}

Two field experiments were conducted at El-Serw Agricultural Research Station, Agricultural Research Center (ARC) in Egypt during the two successive winter seasons of 2011/2012 and 2012/2013. The objective of these experiments was to improve productivity of wheat (variety Sakha 93) under mineral potassium and nitrogen fertilization and increasing efficiency use of applying these fertilizers for wheat. 
The experiments were carried out in a split plot design with four replicates. The main plots were allocated to two potassium fertilizer levels as the following: $\mathrm{K}_{0}(0$ $\left.\mathrm{kg} \mathrm{K} \mathrm{ha}{ }^{-1}\right), \mathrm{K}_{1}\left(47.4 \mathrm{~kg} \mathrm{~K} \mathrm{ha}^{-1}\right)$ and $\mathrm{K}_{2}\left(94.8 \mathrm{~kg} \mathrm{~K} \mathrm{ha}^{-1}\right)$ in the form of potassium sulphate $(39.8 \% \mathrm{~K})$. Potassium fertilizer was applied broadcasting in one dose before the first irrigation. The sub plots were devoted to five nitrogen treatments as follows: A $\left(214 \mathrm{~kg} \mathrm{~N} \mathrm{ha}^{-1}\right), \mathrm{B}\left(178 \mathrm{~kg} \mathrm{~N} \mathrm{ha}^{-1}\right), \mathrm{C}\left(133.5 \mathrm{~kg} \mathrm{~N} \mathrm{ha}^{-1}\right), \mathrm{D}\left(89 \mathrm{~kg} \mathrm{~N} \mathrm{ha}^{-}\right.$ $\left.{ }^{1}\right)$ and $\mathrm{E}\left(44.5 \mathrm{~kg} \mathrm{~N} \mathrm{ha}^{-1}\right)$,the nitrogen fertilizer in the form of ammonium nitrate $(33.5 \% \mathrm{~N})$ was applied at the aforementioned rates in two equal doses prior the first (25 days from sowing) and the second (46 days from sowing) irrigations. Each experimental unit was $3 \times 3.5 \mathrm{~m}$ occupying an area of $10.5 \mathrm{~m}^{2}$.

Calcium superphosphate fertilizer $(6.76 \% \mathrm{P})$ was added at the rate of $238 \mathrm{Kg}$ $\mathrm{ha}^{-1}$ as basal for each plot before ploughing.

Wheat seeds, CV. Sakha 93, were sown on November $18^{\text {th }}$ and $25^{\text {th }}$ in the first and second seasons, respectively. Wheat harvesting was done on $20^{\text {th }}$ April 2012 and 1 May 2013 in both seasons, respectively.

\section{Soil analysis}

Soil samples were taken from the experimental field before conducting from soil layer (0-30 cm depth), then air-dried and ground to pass through $2 \mathrm{~mm}$ sieve. Soil physical and chemical properties were carried out according to Klute (1986) and Page et al. (1982).

TABLE 1. Physical and chemical soil characteristics at the experimental sites during the two seasons

\begin{tabular}{|c|c|c|c|c|c|c|c|c|c|c|}
\hline \multirow[b]{2}{*}{$\begin{array}{c}\text { Growing } \\
\text { season }\end{array}$} & \multicolumn{5}{|c|}{ Particle size distribution\% } & \multirow[b]{2}{*}{$\begin{array}{c}\text { OM } \\
\%\end{array}$} & \multirow[b]{2}{*}{$\underset{\%}{\mathrm{CaCO}_{3}}$} & \multirow[b]{2}{*}{$\begin{array}{c}\text { C.E.C } \\
\text { (meq /100g } \\
\text { soil soil) }\end{array}$} & \multirow[b]{2}{*}{ pH } & \multirow[b]{2}{*}{$\begin{array}{l}\text { EC, } \\
\mathrm{dSm}^{-1}\end{array}$} \\
\hline & $\begin{array}{c}\text { Coarse } \\
\text { sand }\end{array}$ & $\begin{array}{l}\text { Fine } \\
\text { sand }\end{array}$ & Silt & Clay & $\begin{array}{l}\text { Texture } \\
\text { class }\end{array}$ & & & & & \\
\hline $1^{\mathrm{st}}$ & 1.40 & 10.60 & 20.95 & 67.05 & Clayey & 0.75 & 1.39 & 44.95 & 8.0 & 5.20 \\
\hline $2^{\text {nd }}$ & 1.68 & 10.70 & 21.11 & 66.51 & Clayey & 0.82 & 1.31 & 43.32 & 7.8 & 4.40 \\
\hline \multirow{3}{*}{$\begin{array}{l}\text { Growing } \\
\text { season }\end{array}$} & \multicolumn{7}{|c|}{$\begin{array}{l}\text { Cations and anions in the soil water extract }(1: 5), \\
\text { meq/100 g soil }\end{array}$} & \multicolumn{3}{|c|}{ NPK available (ppm) } \\
\hline & \multicolumn{4}{|c|}{ Cations } & \multicolumn{3}{|c|}{ Anions } & $\mathbf{N}$ & $\mathbf{P}$ & K \\
\hline & $\mathrm{Ca}^{++}$ & $\mathrm{Mg}^{++}$ & $\mathrm{Na}^{+}$ & $\mathbf{K}^{+}$ & $\mathrm{HCO}_{3}^{-}$ & $\mathrm{Cl}^{-}$ & $\mathrm{SO}_{4}^{--}$ & N & $P$ & $\mathbf{n}$ \\
\hline $1^{\text {st }}$ & 3.68 & 3.56 & 16.05 & .22 & 1.34 & 16.43 & \begin{tabular}{|ll}
3 & 5.74
\end{tabular} & 30 & 8.02 & 472 \\
\hline $2^{\text {nd }}$ & 3.91 & 3.49 & 16.51 & .24 & 1.51 & 16.81 & 15.83 & 31 & 7.96 & 461 \\
\hline
\end{tabular}

Plant analysis

Nutritional analysis

Oven-dried samples of wheat (grain \& straw) were ground in a mill using a 50-mesh screen. These samples were digested in $\mathrm{H}_{2} \mathrm{SO}_{4}$ concentrated and $\mathrm{H}_{2} \mathrm{O}_{2}$ $30 \%$ according to Yash (1998).

\section{$P$ and $K$ uptake and utilization efficiency}

After wheat harvest, grain and straw yields and $\mathrm{P}$ and $\mathrm{K}$-uptake, by grains and straw were estimated as $\mathrm{kg} \mathrm{ha}^{-1}$ : 
Nutrient element uptake $=($ Nutrient element $\% \times$ Yield $) / 100$

Internal utilization efficiency of a nutrient (Nutrition "Nut." utilization efficiency such as $\mathrm{PU}_{\mathrm{t}} \mathrm{E}$ and $\left.\mathrm{KU}_{\mathrm{t}} \mathrm{E}\right)\left(\mathrm{kg}\right.$ yield. $\mathrm{kg}^{-1}$ nutrient uptake) (Dobermann, 2007) was calculated as follows:

\section{Nut. $-\mathrm{U}_{\mathrm{t}} \mathrm{E}=$ Grain Yield / Nut. uptake by (grain and straw)}

where grain yield as $\mathrm{kg} \mathrm{ha}^{-1}$ and Nut. uptake by (grain and straw) as kg (nutrient element) $\mathrm{ha}^{-1}$.

\section{The statistical analysis}

The statistical analysis was carried out according to Steel and Torrie (1980) to compare the treatments values.

\section{Results}

Grain and straw yield $\left(\mathrm{Mg} \mathrm{ha}^{-1}\right)$

Data presented in Table 2 show that adding potassium and nitrogen fertilizer significantly affected wheat grain and straw yields $\left(\mathrm{Mg} \mathrm{ha}^{-1}\right)$ by increasing potassium fertilizers up to $94.8 \mathrm{~kg} \mathrm{~K} \mathrm{ha}^{-1}$ and nitrogen rate up to $214 \mathrm{~kg} \mathrm{~N} \mathrm{ha}^{-1}$ in both $1^{\text {st }}$ and the $2^{\text {nd }}$ seasons. Baque et al. (2006) and Rahimi (2012) obtained similar result when they treated wheat plant with potassium levels. On the other hand, Abou-Salama et al. (2000), Antoun et al. (2010) and Rahimi (2012) stated that nitrogen fertilizer at the rates of $119.1,178.6$ and $238.1 \mathrm{~kg} \mathrm{~N} \mathrm{ha}^{-1}$ significantly increased yields and its components of wheat.

TABLE 2. Wheat grain and straw yield $\left(\mathrm{Mg} \mathrm{ha}^{-1}\right)$ as affected by the interaction between potassium and nitrogen treatments during 2011/2012 and 2012/2013 seasons

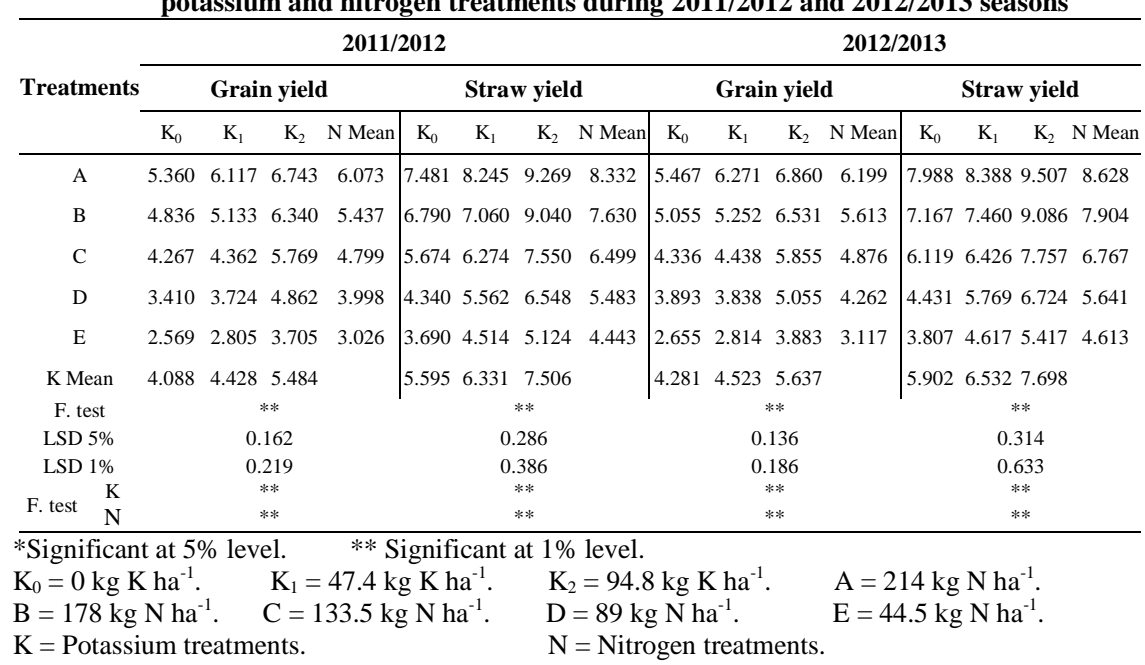

Also, data showed that the interaction between potassium levels and nitrogen treatments had a significant effect on grain and straw yield in both the $1^{\text {st }}$ and the 
$2^{\text {nd }}$ seasons. Also, Table 3 shows that, the highest values of wheat grain yield $\left(6.743 \& 6.860 \mathrm{Mg} \mathrm{ha}^{-1}\right)$ and straw yield $\left(9.269 \& 9.507 \mathrm{Mg} \mathrm{ha}^{-1}\right)$ were obtained when $94.8 \mathrm{~kg} \mathrm{~K}^{-1}$ overlapped with $214 \mathrm{~kg} \mathrm{ha}^{-1}$ in 1 st and 2nd seasons, respectively, the following highest values of wheat grain yield were obtained with $\left(\mathrm{K}_{2} \times \mathrm{B}\right),\left(\mathrm{K}_{1} \times \mathrm{A}\right),\left(\mathrm{K}_{2} \times \mathrm{C}\right)$ and $\left(\mathrm{K}_{0} \times \mathrm{A}\right)$, respectively. The conclusion from this is the important role of potassium for wheat grain production, where $94.8 \mathrm{~kg} \mathrm{~K} \mathrm{ha}{ }^{-1}$ is preferably added for economic crop of wheat, also for producing the best wheat yield in saline soil $\left(\mathrm{Ec}>4 \mathrm{dS} \mathrm{m}^{-1}\right)$, it is preferable to add $214 \mathrm{~kg} \mathrm{~N} \mathrm{ha}^{-1}$ and $94.8 \mathrm{~kg} \mathrm{~K} \mathrm{ha}^{-1}$.

Phosphorus uptake by wheat grain and straw $\left(\mathrm{kg} \mathrm{P} \mathrm{ha}^{-1}\right)$

Data in Table 3 show that there was significant increase in phosphor uptake by both wheat grain and straw (total phosphorus removed by the crop from the soil in grain and straw) in both the $1^{\text {st }}$ and the $2^{\text {nd }}$ seasons due to appling potassium and nitrogen fertilizers levels.

Also, as in previous variables, the highest values of $\mathrm{P}$ uptake were obtained with applying $214 \mathrm{~kg} \mathrm{~N} \mathrm{ha}^{-1}$ as nitrogen factor and $94.8 \mathrm{~kg} \mathrm{~K} \mathrm{ha}^{-1}$ as potassium treatments, where there was a positive relationship between each factor separately (potassium or nitrogen) and $\mathrm{P}$ uptake. Baque et al. (2006) reported that uptake of $\mathrm{P}$ was enhanced with the increasing potassium levels. But Antoun et al. (2010) obtained similar results when they used nitrogen treatments.

Also, data in Table 3 show that interaction effect between potassium and nitrogen treatments was significant on $\mathrm{P}$ uptake by wheat grain and straw in both 2011/2012 and 2012/2013 seasons. The highest values of P uptake for wheat grains in both 2011/2012 and 2012/2013 seasons were obtained with $214 \mathrm{~kg} \mathrm{~N}$ $\mathrm{ha}^{-1}$ and $178 \mathrm{~kg} \mathrm{~N} \mathrm{ha}^{-1}$, respectively when applied with $94.8 \mathrm{~kg} \mathrm{~K} \mathrm{ha}^{-1}$. But the highest values of $\mathrm{P}$ uptake for wheat straw in both the $1^{\text {st }}$ and the $2^{\text {nd }}$ seasons were with $\left(\mathrm{K}_{2} \times \mathrm{A}\right),\left(\mathrm{K}_{1} \times \mathrm{A}\right)$ and $\left(\mathrm{K}_{2} \times \mathrm{B}\right)$, respectively.

TABLE 3. Phosphorus uptake $\left(\mathrm{kg} \mathrm{Pha}^{-1}\right)$ by grain and straw of wheat plant as affected by the interaction between potassium and nitrogen treatments during 2011/2012 and 2012/2013 seasons

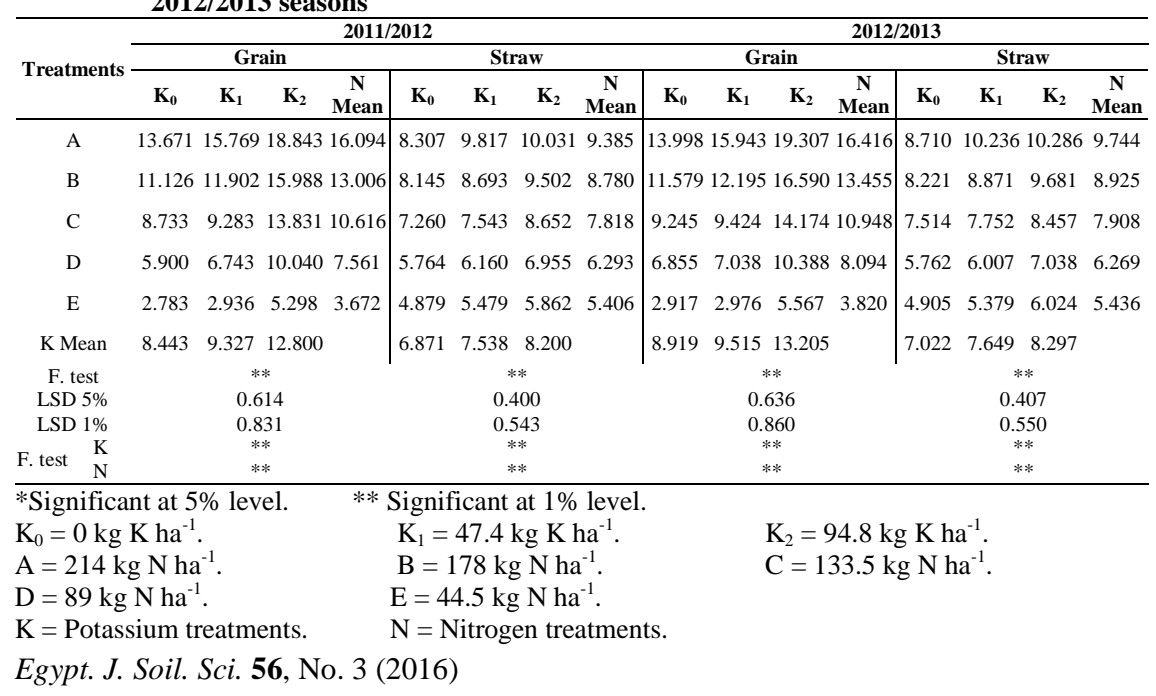


Potassium uptake by wheat grain and straw $\left(\mathrm{kg} \mathrm{Kha}^{-1}\right)$

Data presented in Table 4 show that potassium uptake significantly increased by wheat grain and straw (total potassium removed by the crop from the soil in grain and straw) in both the $1^{\text {st }}$ and $2^{\text {nd }}$ seasons due to potassium treatments. Also, the highest mean value of $\mathrm{K}$ uptake was obtained with $94.8 \mathrm{~kg} \mathrm{~K} \mathrm{ha}^{-1}$. Baque et al. (2006) obtained similar results.

Also, there was significant increment in $\mathrm{K}$ uptake by wheat grain and straw in both the $1^{\text {st }}$ and the $2^{\text {nd }}$ season, by nitrogen treatments, the highest mean values of $\mathrm{K}$ uptake by grains and straw in both the $1^{\text {st }}$ and the $2^{\text {nd }}$ seasons were recorded with A, B, C, D and E, respectively. Similar results were obtained by Antoun et al. (2010). Such as $\mathrm{P}$ uptake, also, there was a positive relationship between each factor separately (potassium or nitrogen) and K uptake.

Also, data in Table 4 show that interaction effect between potassium and nitrogen treatments was significant on $\mathrm{K}$ uptake by wheat straw in both $1^{\text {st }}$ and $2^{\text {nd }}$ seasons and wheat grain in the $1^{\text {st }}$ season, but, this effect was significant at $5 \%$ in wheat grain in the $2^{\text {nd }}$ season. The highest values of $\mathrm{K}$ uptake for wheat grains and straw in both the $1^{\text {st }}$ and the $2^{\text {nd }}$ seasons, were obtained with $\left(\mathrm{K}_{2} \times \mathrm{A}\right)$, $\left(\mathrm{K}_{2} \times \mathrm{B}\right)$ and $\left(\mathrm{K}_{1} \times \mathrm{A}\right)$, respectively.

TABLE 4. Potassium uptake $\left(\mathrm{kg} \mathrm{K} \mathrm{ha}^{-1}\right)$ by grain and straw of wheat plant as affected by the interaction between potassium and nitrogen treatments during 2011/2012 and 2012/2013 seasons

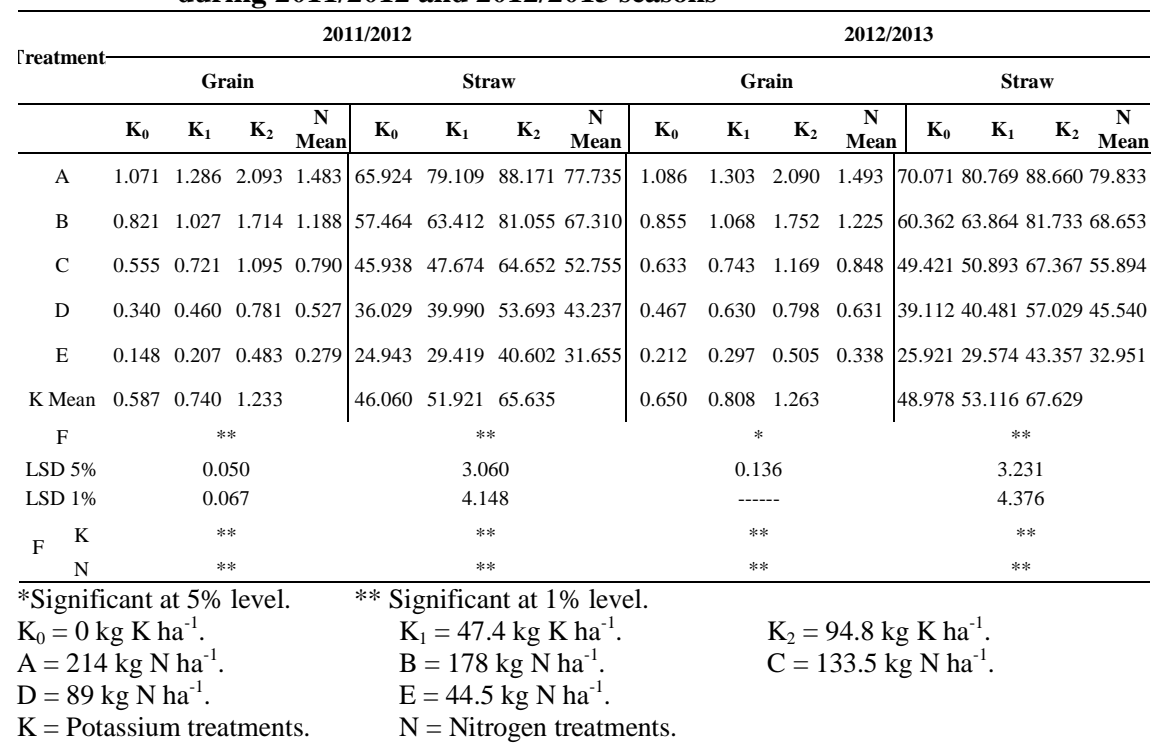

Phosphorus Utilization Efficiency $\left(P U_{t} E\right)\left(k g\right.$ grain $k g P$ uptake $\left.{ }^{-1}\right)$ by wheat crop Data in Table 5 showed that there was no significant decrease in $P U_{t} E$ in both $1^{s t}$ and the $2^{\text {nd }}$ seasons by increasing potassium fertilizer rates up to $94.8 \mathrm{~kg} \mathrm{~K}$ $\mathrm{ha}^{-1}$. But, there was significant increment in $\mathrm{PU}_{\mathrm{t}} \mathrm{E}$ due to applying nitrogen 
fertilizer in both seasons. The highest value of $\mathrm{PU}_{\mathrm{t}} \mathrm{E}$ was obtained with $\mathrm{E}$ followed by D, C, B and A treatments.

Also, Data showed the effect of the interactions among potassium application and nitrogen treatments on phosphorus utilization efficiency for wheat crop in the $1^{\text {st }}$ and $2^{\text {nd }}$ seasons. This interaction was not significantly decreased in $\mathrm{PU}_{\mathrm{t}} \mathrm{E}$ for wheat crop in both seasons. The highest values of $\mathrm{PU}_{\mathrm{t}} \mathrm{E}$ were obtained by this interaction were with $\left(\mathrm{K}_{0} \times \mathrm{E}\right),\left(\mathrm{K}_{1} \times \mathrm{E}\right)$ and $\left(\mathrm{K}_{2} \times \mathrm{E}\right)$, respectively.

Potassium Utilization Efficiency $\left(K U_{t} E\right)$ ( $k g$ grain $k g ~ K$ uptake $\left.^{-1}\right)$ by wheat crop

Data in Table 5 showed that there was significant decrease in $\mathrm{KU}_{\mathrm{t}} \mathrm{E}$ in both the $1^{\text {st }}$ and $2^{\text {nd }}$ seasons by increasing potassium fertilizer rates up to $94.8 \mathrm{~kg} \mathrm{~K} \mathrm{ha}$ ${ }^{1}$. Also, there was significant increment in $\mathrm{KU}_{\mathrm{t}} \mathrm{E}$ by applying nitrogen fertilizer in both seasons. The highest value of $\mathrm{KU}_{\mathrm{t}} \mathrm{E}$ was obtained with $\mathrm{E}, \mathrm{D}, \mathrm{C}, \mathrm{B}$ and $\mathrm{A}$, respectively.

Also, Data showed that the effect of the interactions between potassium application and nitrogen treatments on potassium utilization efficiency by wheat crop was not significantly decreased in both the $1^{\text {st }}$ and the $2^{\text {nd }}$ seasons. The highest values of $\mathrm{KU}_{\mathrm{t}} \mathrm{E}$ were obtained by this interaction were with $\left(\mathrm{K}_{0} \times \mathrm{E}\right),\left(\mathrm{K}_{1}\right.$ $\times \mathrm{E})$ and $\left(\mathrm{K}_{0} \times \mathrm{D}\right)$, respectively in the $1^{\mathrm{st}}$ season and $\left(\mathrm{K}_{0} \times \mathrm{E}\right),\left(\mathrm{K}_{0} \times \mathrm{D}\right)$ and $\left(\mathrm{K}_{1} \times\right.$ $\mathrm{E})$, respectively in the $2^{\text {nd }}$ season.

TABLE 5. PU $\mathrm{t}_{\mathrm{t}} \mathrm{E}$ and $K \mathrm{~K}_{\mathrm{t}} \mathrm{E}$ by wheat crop as affected by the interaction between potassium and nitrogen treatments during 2011/2012 and 2012/2013 seasons.

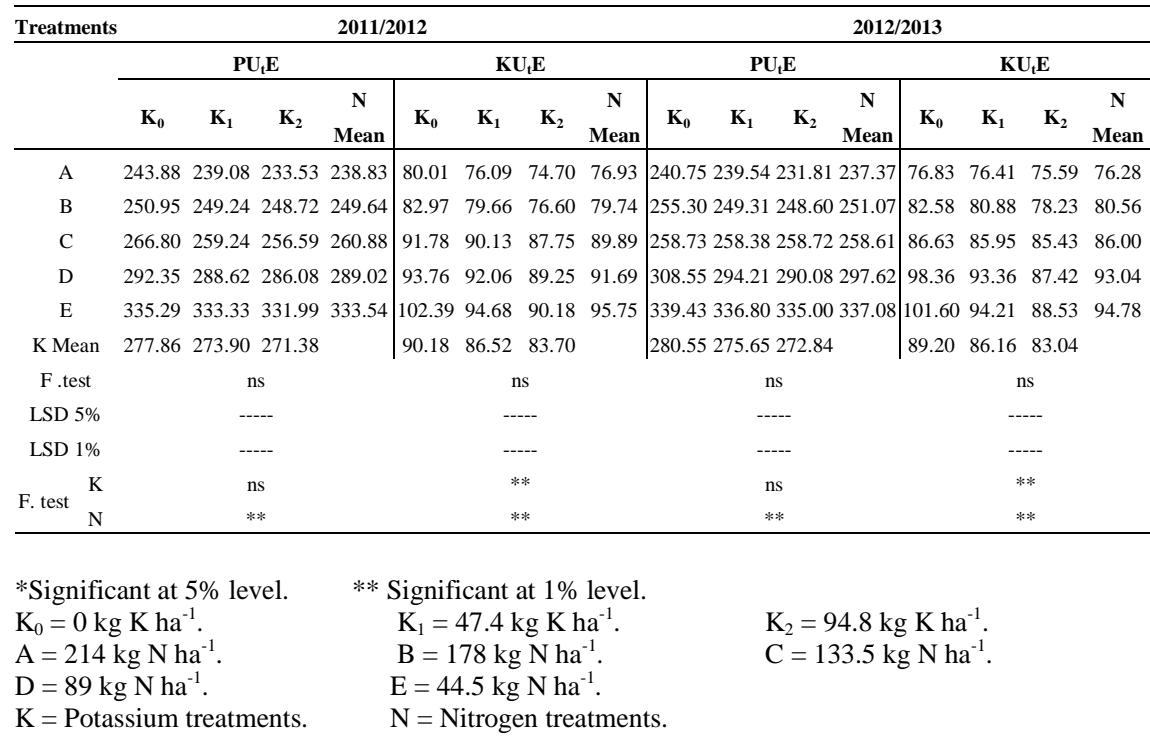




\section{Discussion}

\section{Grain and straw yield}

Wheat grain and straw yields (Mg ha-1) increased by increasing potassium fertilizers up to $94.8 \mathrm{~kg} \mathrm{~K}$ ha-1, this is due to the limited $\mathrm{K}$ supply which slows plant growth and decreases biomass production, thus increasing potassium fertilization consequently causes to increase production of grain and straw. These interpretations matching to came out (Hermans et al. 2006 and Rengel \& Damon, 2008). Pettigrew (2008) pointed to the importance of potassium due to its involvment in many physiological processes, potassium impact on water relations, photosynthesis, assimilate transport and enzyme activation can have direct consequences on crop productivity. Also, increased nitrogen fertilization led to increased production of wheat yield due to strong response to additions of nitrogen, which is regarded as the main element in the construction of amino acids, proteins and enters in many physiological processes in the plant. Also, potassium and nitrogen fertilization can strongly affect crop productivity under conditions of salinity, due to that the addition of nutrients can either enhance or decrease plants' resistance to salinity by helping plant to strong growth, thus increasing the wheat yield with increased potassium and nitrogen fertilization as the most important elements for plant growth under saline soil.

Phosphorus and potassium uptake by wheat grain and straw

Increasing phosphorus and potassium uptake by increasing potassium and nitrogen fertilization, due to the potassium and nitrogen are the most important nutrients for plants, where many physiological processes rely on them, especially those responsible for absorbing elements by enhancing roots and thus increasing the concentration of nutrients in plant such as phosphorus and potassium. Baque et al. (2006) reported that uptake of $\mathrm{P}$ was enhanced with the increasing potassium levels. But Antoun et al. (2010) obtained similar results when they used nitrogen treatments.

\section{$P U_{t} E$ and $K U_{t} E$ by wheat}

From the foregoing it is clear that nitrogen deficiency leads to high of PUtE and KUtE. This increase in PUtE and KUtE indicates that there is a decrease in phosphorus and potassium uptake. Therefore, nitrogen deficiency leads to phosphorus and potassium deficiency even with the availability in the soil absorption plant. This interpretation is consistent with Dobermann (2007) who indicated that very high nutrients utilization efficiency suggests deficiency of that nutrient.

\section{Conclusion}

It could be concluded the important role of potassium and nitrogen in wheat production, preferably added at $94.8 \mathrm{~kg} \mathrm{~K} \mathrm{ha}^{-1}$ and $214 \mathrm{~kg} \mathrm{~N} \mathrm{ha}^{-1}$ for economic crop of wheat especially in saline soil. Nitrogen deficiency leads to high symptoms of phosphorus and potassium deficiency even with the availability in the soil absorption plant. 
Acknowledgements: The research was financially supported by Soils, Water and Environment Research Institute, Agricultural Research Center, Egypt.

\section{References}

Abou-Salama, A.M., Ismai, A.A., Teama, E. A. and Kheiralla, K. A. (2000) Yield response of some wheat lines to nitrogen fertilization under two soils types. Assiut J. Agric. Sci., 31 (2), 175-187.

Ahmed, S. M. M. (2002) Response of some wheat cultivars to nitrogen and phosphorus fertilization under sandy soil condition. Zagazig J. Agric. Res., 29 (4), 264-278.

Antoun, L. W., Zakaria, S. M. and Rafla, H. H. (2010) Influence of compost, Nmineral and humic acid on yield and chemical composition of wheat plants. J. Soil Sci. and Agric. Engi., Mansoura Univ., 1(11), 1131- 1143.

Baligar, V. C., Fageria, N. K. and He, Z. L. (2001) NUTRIENT USE EFFICIENCY IN PLANTS, Communications in Soil Science and Plant Analysis, 32, 7-8, 921-950.

Baque, M. A., Karim, M.A., Hamid, A. and Tetsushi, H. (2006) Effects of fertilizer potassium on growth, yield and nutrient uptake of wheat (Triticum aestivum L.) under water stress conditions. South Pacific Studies, 27 (1), 25-35.

Cassman, K. G., Dobermann, A. and Walters, D. (2002) Agroecosystems, nitrogenuse efficiency, and nitrogen management. Ambio. 31, 132-140.

Damon, P. and Rengel, Z. (2007) Wheat genotypes differ in potassium efficiency under glasshouse and field conditions. Aust. J. Agr. Res. 58, 816-825.

Dobermann, A. (2007) Nutrient use efficiency - measurement and management. The IFA International Workshop on Fertilizer Best Management Practices, 7-9 March 2007, Brussels, Belgium, 1-32.

El Bassam, N. (1998) A concept of selection for 'low input' wheat varieties. Euphytica 100,153-158.

El-Abady M. I., Seadh, S. E. Abeer El-Ward, Ibrahim, A. and El-Emam, A. A. M. (2009) Irrigation withholding and potassium foliar application effects on wheat yield and quality. Int. J. Sustain. Crop Prod., 4 (4), 33-39.

Gibson, T. S. (1988) Carbohydrate metabolism and phosphorus-salinity interactions in wheat (Triticum aestivum L.). Plant and Soil, 111, 25-35.

Hermans, C., Hammond, J., White, P. and Verbruggen, N. (2006) How do plants respond to nutrient shortage by biomass allocation? Trends Plant Sci., 11, 610-617.

Klute, A. (1986) Methods of Soil Analysis part 1, Physical and Mineralogical Methods. Am. soc. of Agrom.and Am.soc.soil sci.Methods Madison,Wisconsin,USA. 
Matson, P. A., Naylor, R. and Ortiz-Monasterio, I. (1998) Integration of environmental, agronomic, and economic aspects of fertilizer management. Science, 280, $112-115$.

Page, A.L, Miller,R.H. and Keeny, D.R., (1982) Methods of Soil Analysis part 2. Chemical and Microbiological Properties $2^{\text {nd }}$ ed. Am. Soc.of Agrom., Madison, Wisconsin, USA.

Pettigrew, W. T. (2008) Potassium influences on yield and quality production for maize, wheat, soybean and cotton. Physiologia Plantarum, 133, 670-681.

Rahimi, A. (2012) Effect of potassium and nitrogen on yield and yield components of dry land wheat in Boyerahmad Region of Iran. Annals of Biol. Res., 3 (7), 3274-3277.

Rengel, Z. and Damon, P. (2008) Crops and genotypes differ in efficiency of potassium uptake and use. Physiol Plant, 133, 624-636.

Seleem, S. A. and Abd El-Dayem, S. M. (2013) Response of some wheat cultivars to nitrogen fertilizer levels. J. Plant Production, Mansoura Univ., 4(5), 721 - 731.

Siddiqi, M. and Glass, A. (1981) Utilization index: a modified approach to the estimation and comparison of nutrient utilization efficiency in plants. J. Plant Nutr. 4, 289-302.

Steel, R. G. D. and Torrie, J. H. (1980) Principles and Procedures of Statics,2nd ed. Mc Graw Hill International Book Company, New York, USA.

Tababtabaei, S. A. and Ranjbar, G. H. (2012) Effect of different levels of nitrogen and potassium on grain yield and protein of wheat. Intern. Res. J. Appl. Basic. Sci., 3(2), 390-393.

Trehan, S. and Sharma, R. (2002) Potassium uptake efficiency of young plants of three potato cultivars as related to root and shoot parameters. Commun. Soil Sci. Plan, 33, $1813-1823$

Yash, P. K. (1998) Handbook Reference Methods for Plant Analysis. Taylor \& Francis Group, London.

Zhang, H., Rong, H. and Pilbeam, D. (2007) Signalling mechanisms underlying the morphological responses of the root system to nitrogen in Arabidopsis thaliana. J. Exp Bot. 58, 2329-2338.

(Received 31/5/2015;

Accepted 1/10/2015) 


\section{تأثير التسميد البوتاسى والنيتروجينى على كفاءة إستخدام بعض العناصر الغذائية للقمح}

إبراهيم سعيد محمد مسعد و كريم فكرى فودة"

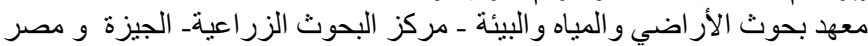

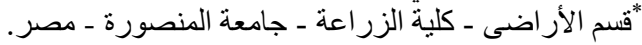

لاراسة تأثير معاملات من التسميد البوتاسى والنيتروجين على محصول القمح

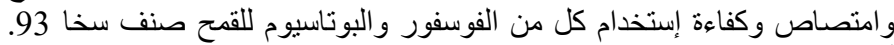

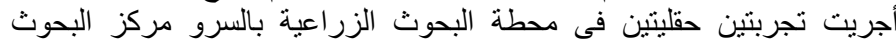

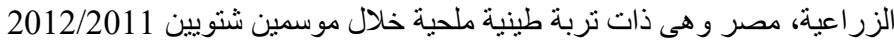

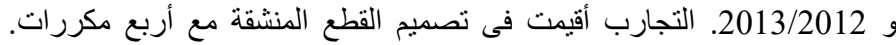

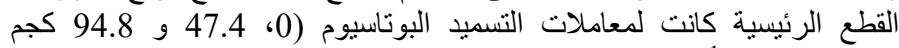

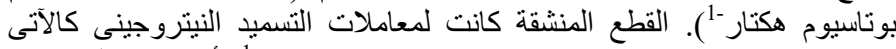

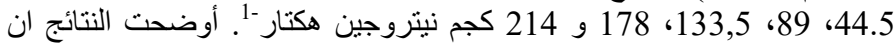

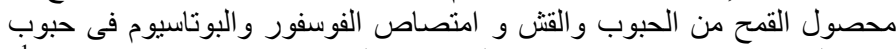

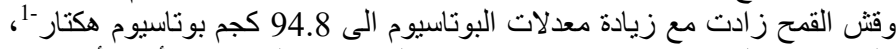

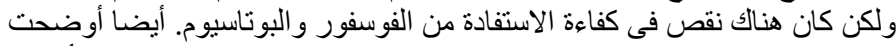

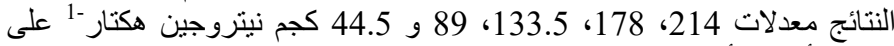

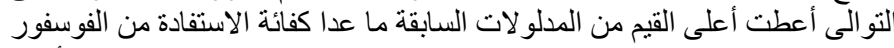

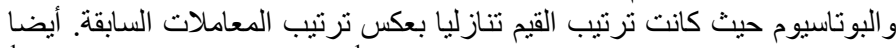

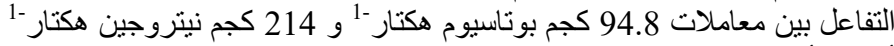

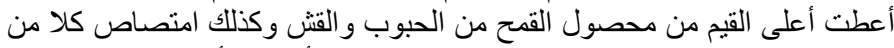

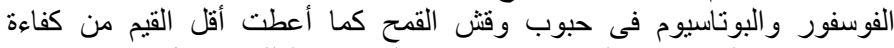

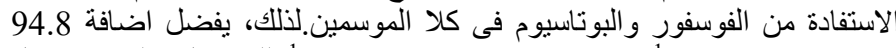

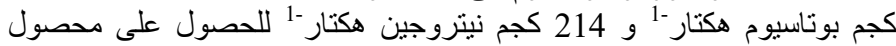

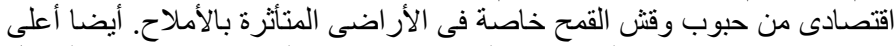

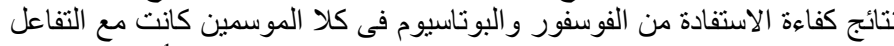

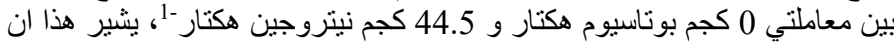

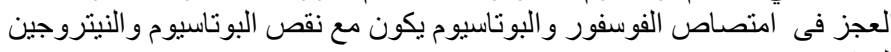
المتاحيين. 